Original Research Paper

\title{
Influence of Bitumen Addition on Sabkha Soil Shear Strength Characteristics under Dry and Soaked Conditions
}

\author{
${ }^{1}$ Fahad A. Alotaibi and ${ }^{2}$ Humoud Melfi Aldaihani \\ ${ }^{1}$ Associate Professor, Department of Civil Engineering, College of Technological Studies (CTS), \\ The Public Authority for Applied Educational Training (PAAET), Shuwaikh, Kuwait \\ ${ }^{2}$ Full Time as Civil Engineering Consultant at Environment Affairs Department at Ministry of Public Works (MPW), Kuwait, \\ Part Time Assistant Professor, Department of Civil Engineering, CTS, PAAET, Shuwaikh, Kuwait,
}

Article history

Received: 25-09-2018

Revised: $30-10-2018$

Accepted: 10-11-2018

Corresponding Author:

Fahad A. Alotaibi

Department of Civil

Engineering, College of

Technological Studies (CTS),

Public Authority for Applied

Educational Training (PAAET),

Shuwaikh, Kuwait

Email:fo.alotaibi@paaet.edu.kw

\begin{abstract}
High salt content in sabkha soils means they are significantly affected by changes in water content. Dissolution of salts within sabkha soil mass decreases their shear strength upon inundation with water, resulting from the destruction of cementation bonds between soil particles. Therefore, successful improvement for these soils must be based on reducing the dissolution of sabkha salts to minimize their unfavorable properties. This paper investigated the effect of bitumen addition as a stabilizing waterproofing agent on the shear strength properties of sabkha soil. $0 \%, 4 \%, 8 \%$ and $10 \%$ bitumen and sabkha soil were mixed thoroughly. The experimental program on the bitumenmixed sabkha soils included physical and chemical soil characterization, modified compaction tests and direct shear strength tests. The results showed that bitumen addition modified the physical properties by up to $8 \%$. Under dry conditions, the ultimate shear strength and the horizontal shear displacement increased with bitumen addition. Under soaked conditions, the improvement in shear strength properties was pronounced. The shear strength parameters for the natural sabkha soil fell upon soaking, while the bitumen-mixed sabkha soil samples maintained their integrity. The adsorbed bitumen layer on the cemented soil lumps acted as a waterproofing agent that reduced salt dissolution and alternatively, the shear strength.
\end{abstract}

Keywords: Bitumen, Chemical Properties, Physical Properties, Sabkha, Soil, Shear Strength Properties

\section{Introduction}

In Kuwait, the semi-arid environment, characterized by high evaporation and low precipitation rates, has resulted in the concentration of different types of salts in the surface soil layer. These layers, which concentrate in north and south Kuwait, are known as sabkha soils. The soils are marked by high concentrations of cementing agents, including gypsum, carbonates and chlorides (Al-Amoudi, 1994; Ismael and Mollah, 1998). In addition, sabkha soils are known for their low-bearing strength (AlAmoudi, 2002; Al-Shamrani and Dhowian, 1997), high susceptibility to collapse (Al-Amoudi and Abduljauwad, 1995) and high volume changes (Ismael, 1993). This composition of sabkha soils means that their geotechnical properties are highly affected by salt dissolution.
Limited soil resources in Kuwait suggest the need to introduce modifications to sabkha soils to create more resources, especially for minor construction purposes. Therefore, stabilization of sabkha soils would reduce the overuse of the limited natural soil resources in Kuwait. Furthermore, an effective stabilization mechanism for sabkha soils should be based on reducing the ability of soil particles to absorb surface water. This is because this reduces salt dissolution, thereby increasing the stability of the soil structure.

Bituminous materials are considered the main waterproofing agents that that are regularly used as effective stabilizing agents. The basic mechanisms involved in the bituminous stabilization of fine-grained soils are the waterproofing phenomenon and the adhesion 
effect (DANA, 1994; Ingles and Metcalf, 1972). Despite the publication of multiple studies addressing the possibility of improving the engineering specifications of sabkha soils using asphalt cement, cutback asphalt or asphalt emulsion soils (Asi, 2001; Asi et al., 2002; AlAbdul Wahhab and Asi, 1997; Al-Amoudi et al., 1995), the wide variation in the chemical of these. A variety of properties, including measures of strength, density, durability and shrinkage, can be measured as outcomes of stabilization. The most significant parameter is the soil compaction property. Maximum Dry Density (MDD) of stabilized soils is generally an important factor in determining the soil suitability or unsuitability for stabilization. MDD is well-established as a measure of the outcome of stabilization (Akpokodje, 1985; Bell, 1996; Ngowi, 1997). In summary, improvement to the soil compaction properties will improve the bearing capacity. Based on the existing studies, it is clear that an appropriate stabilizer percentage can be selected according to the compaction parameters criterion. Based on this, the percentage of bitumen content, which provides the MDD, was considered the optimum amount of bitumen for the soil.

Researchers have long insisted that sabkha soils must continue to be investigated, mainly to create confidence in using such types of soil. Accordingly, it was felt necessary to investigate the behavior of natural and bitumen-mixed sabkha soils under dry and soaked conditions. This would permit inspection of the effect of bitumen addition on shear strength parameters.

The main objective of this study was to investigate the effect of bitumen addition on the shear strength characteristics of sabkha soil under both dry and soaked conditions. In the experiment, different concentrations of bitumen content were mixed thoroughly with sabkha soil samples. The optimum bitumen content was obtained by running compaction tests. Direct shear tests were performed on $0 \%, 4 \%$ and $8 \%$ bitumen content sabkha soil samples.

Results were expected to illuminate the shear strength behavior of bitumen-mixed sabkha soil samples. In turn, such findings could help to improve efforts to solve the geotechnical problems concerning one of the main surface deposits of the arid soils in Kuwait.

\section{Materials and Experimental Program}

\section{Materials}

\section{Soil Sampling Location}

The soil used in this study was obtained from a sampling site in the Mina Abdulla area. The area is part of the southern sabkha flats that extend along the southern coastal area of Kuwait. Sabkha soil samples were collected from a zone previously investigated by Al-Otaibi et al. (2012). Additionally, the samples were collected during the summer months in 2017 to obtain the highest salt concentrations, particularly after a high and long evaporation summer. This period in the year also facilitated soil sampling, since sabkha flats can be expected to exhibit stable ground conditions for sampling purposes due to the cementation effect of different salt layers and crystals.

\section{Soil Sample Preparation}

The collected, disturbed sabkha soil samples were oven-dried in the laboratory, ensuring that the oven temperature did not exceed $60^{\circ} \mathrm{C}$ for three days. This measure stemmed from the fact that salt-bearing soils are affected by the temperature (Ismael, 1993). Soil particles were gently crushed with a plastic hammer and the materials were passed through a 4.75-mm (No. 4-mesh) sieve. Materials were thoroughly mixed, homogenized and separated into two portions.

Different specimens were air-dried, weighed and mixed with $0 \%, 4 \%, 8 \%$ and $10 \%$ bitumen by weight. The cut-back bitumen was prepared using a specific percentage of bitumen with an added percentage of kerosene, as per the manufacturer's specification. The percentages were selected based on previous studies, which indicated that the optimum bitumen content ranged from 3\% to $12 \%$ (Al-Otaibi and Wegian, 2012; Al-Otaibi, 2006).

The cut-back bitumen and sabkha soil were manually mixed until satisfactorily homogenous, determined through visual observation. Then, the mixture was remixed for one minute using a mechanical mixer. The mixture was then oven-dried to a maximum temperature of approximately $60^{\circ} \mathrm{C}$ for three days, the intention being to simulate field conditions and evaporate the material used for the cut-back bitumen.

\section{Experimental Program}

\section{Physical and Chemical Tests}

Natural and bitumen-mixed sabkha soil samples were subjected to both mechanical sieve and hydrometer analyses according to ASTM D-422 (1998). The liquid and plastic limit tests for the sabkha soil samples were carried out according to ASTM D-4318 (1995). Sabkha soil samples were classified according to the Unified Soil Classification System (ASTM D-2487, 1999). The specific gravity (Gs) or particle density of different soil samples was determined according to ASTM D-854 (2014).

Modified Proctor compaction tests were performed according to ASTM D-1557 (2012). Furthermore, chemical testing was carried out on a representative sample to complete sabkha soil characterization.

\section{Shear Strength Tests}

Several direct shear tests were performed to determine the shear strength parameters of natural and bitumen- 
mixed sabkha soil samples soils with different bitumen percentages under OMC. The tests were performed according to the procedure proposed by ASTM D-3080 (1998). $60 \times 60 \times 20 \mathrm{~mm}$ soil specimens were used.

Vertical loads were applied incrementally to provide varying vertical stresses of 50, 100, 150, 200 and $400 \mathrm{kPa}$. Each vertical stress was allowed to remain in place for a pre-determined period of time, specifically, until the full settlement of the specimen occurred. The tests were conducted under a low shearing speed of $0.120 \mathrm{~mm} / \mathrm{min}$, thereby ensuring the total dissipation of the pore water pressure. During the shearing process, readings of vertical and shear displacements and shear forces were recorded at convenient time intervals. The time interval for taking a reading was selected as $30 \mathrm{sec}$.

The second series was performed on samples prepared in a similar way to the first, but this time, the samples were soaked in water. Specifically, the tested soil samples were soaked for $24 \mathrm{~h}$ before carrying out the test.

\section{Results and Discussion}

\section{Soil Physical Analysis}

The specific gravity value of the soil was 2.7 , which is within the range of the specific gravity values of the southern sabkha soils in Kuwait, as reported by Al-Otaibi (2006) and Al-Otaibi et al. (2012). The grain size distribution curves resulting from the sieve and hydrometer tests for natural and bitumenmixed sabkha soils are shown in Fig. 1. As the figure indicates, bitumen-mixed sabkha becomes coarser with a rise in the percentage of bitumen. Soil aggregation may be attributed to the effect of the adsorbed bitumen on the soil particle surfaces. Similar results were observed in several studies addressing contaminated oil residue and bitumen-stabilized soils, but these studies attributed the phenomenon to an adsorbed viscous layer (Aldaihani, 2017; Al-Otaibi, 2006; Al-Otaibi et al., 2012).

The liquid and plastic limits for the natural sabkha were 39 and 20, respectively. The bitumen sabkha was non-plastic; therefore, it was not possible to measure the liquid and plastic limits. Natural sabkha soil was classified according to the Unified Soil Classification System (ASTM D-2487, 1999) as a clayey sand (SCL), while bitumen-mixed sabkha soil samples were classified as poorly graded SP.

The physical properties of the natural and bitumenmixed sabkha soil samples are summarized in Table 1. Soil gradation results are in good agreement with the findings reported by Al-Otaibi (2006), whose study focused on oil lake residue stabilized sabkha soils.

\section{Soil Chemical Composition Analysis}

The chemical analysis of the tested sabkha soil sample is presented in Table 2 . The results revealed that silicon dioxide $\left(\mathrm{SiO}_{2}\right)$ was the predominant component in the sabkha soil, accounting for $42.20 \%$. This was followed by calcium carbonate $(18.20 \%)$, calcium oxide $(16.20 \%)$ and sulphate $(12.17 \%)$. Notably, the results are consistent with the previous studies conducted in southern Kuwait (Al-Otaibi, 2006; Al-Otaibi et al., 2012).

\section{Soil Compaction Analysis}

Modified Proctor compaction tests were applied on natural and $4 \%, 8 \%$ and $10 \%$ bitumen-mixed sabkha soil samples, as illustrated in Fig. 2. The Maximum Dry Density (MDD) and Optimum Moisture Content (OMC) values for the tested soil samples are summarized in Table 1.

The results indicated that the compaction characteristics of the sabkha soil were modified by a bitumen addition of up to $8 \%$. Beyond this percentage, the MDD decreased to a value lower than the natural sabkha. It was also observed that $8 \%$ bitumen-mixed sabkha displayed better compaction characteristics compared to the natural Sabkha. The increase in the MDD may be attributed to the higher compactness of the $8 \%$ bitumenmixed sample than the natural sabkha. The viscous bitumen layer, underpinned by the sliding of soil particles and denser soil, was attained at lower moisture content.

\section{Soil Shear Strength Analysis}

\section{Shear Stress Versus Shear Displacement - Dry Conditions}

The shear resistance of soil is the result of friction and interlocking particles. The shear strength parameters for soils are defined as the internal angle of friction $(\varphi \mathrm{f})$ and the cohesion intercept (C). Therefore, bitumen addition is likely to influence shear strength, where the shear strength parameters result from the frictional forces of the particles as they slide and interlock during shearing. Direct shear tests were performed to investigate the effect of bitumen addition on the shear strength of the sabkha soil samples in terms of $\varphi \mathrm{f}$ and $\mathrm{C}$.

Figure 3 presents the results from the direct shear tests on natural $0 \%, 4 \%$ and $8 \%$ bitumen content at vertical stress $100 \mathrm{kPa}$, tested under dry conditions. The figure illustrates the shear stress versus the shear (horizontal) displacement for the tested samples. Clearly, the shearing stress for the samples increased at different rates up to the peak shear stress. A comparison of the peak shear strength shows that peak shear stresses at normal stresses of $100 \mathrm{kPa}$ were $110 \mathrm{kPa}, 123 \mathrm{kPa}$ and $182 \mathrm{kPa}$ for $0 \%, 4 \%$ and $8 \%$, respectively. This reflects an increase of $12 \%$ and $65 \%$ for $4 \%$ and $8 \%$ bitumen compared with the natural soil at similar vertical stresses. In addition, the stress-strain curves show that the pre-failure portion of the shear stress against the horizontal displacement curves was affected by bitumen addition. The resulting peak shear stresses increased with 
bitumen addition and the shear displacement levels were higher for the bitumen-mixed samples than the natural samples. Once a peak had been reached for the tested soils, a reduction in shear stresses was observed with an increase in the strain. Bitumen-mixed soils exhibited a lower reduction in shear stress compared to natural soil. The strongly cemented sabkha soil samples displayed the brittle failure mode, since the degree of brittleness increases sharply with the amount of cement material (Ismael et al., 1986).

Table 1: Index properties of tested soil samples

\begin{tabular}{|c|c|c|c|c|c|c|c|c|c|c|c|}
\hline Bitumen \% & $D_{10}$ & $D_{30}$ & $\mathrm{D}_{60}$ & $\mathrm{C}_{\mathrm{U}}$ & $\mathrm{C}_{\mathrm{C}}$ & LL & PL & $\begin{array}{l}\text { Unified soil } \\
\text { classification }\end{array}$ & GS & MDD & $\mathrm{OMC}$ \\
\hline $0 \%$ & 0.032 & 0.09 & 0.26 & 8.1 & 1.0 & 39 & 20 & SCL & 2.7 & 1.885 & 13.2 \\
\hline $4 \%$ & 0.078 & 0.15 & 0.31 & 4.0 & 0.9 & - & - & $\mathrm{SP}$ & - & 1.865 & 14.3 \\
\hline $8 \%$ & 0.079 & 0.155 & 0.32 & 4.1 & 1.0 & - & - & SP & - & 1.925 & 9.25 \\
\hline $10 \%$ & 0.100 & 0.200 & 0.46 & 4.6 & 0.9 & - & - & SP & - & 1.875 & 9.1 \\
\hline
\end{tabular}

Table 2: Chemical composition of sabkha soil sample

\begin{tabular}{lllllllll}
\hline $\mathrm{SiO}_{2} \%$ & $\mathrm{CaCO}_{3} \%$ & $\mathrm{CaO} \%$ & $\mathrm{SO}_{4}{ }^{2-} \%$ & $\mathrm{MgO} \%$ & $\mathrm{Al}_{2} \mathrm{O}_{3} \%$ & $\mathrm{Fe}_{2} \mathrm{O}_{3} \%$ & $\mathrm{Na}_{2} \mathrm{O} \%$ & Organic Content \% \\
\hline 42.10 & 18.20 & 16.2 & 12.17 & 3.20 & 3.75 & 1.55 & 1.24 & 0.65 \\
\hline
\end{tabular}

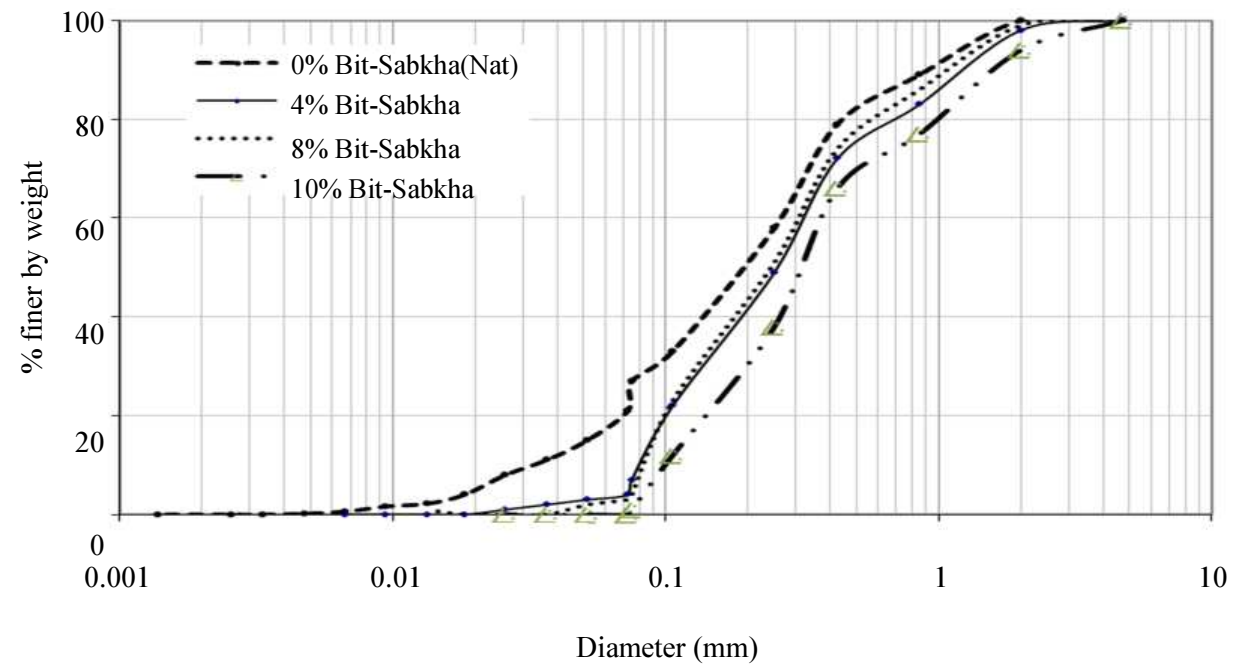

Fig. 1: Grain size distribution for natural bitumen mixed sabkha soils

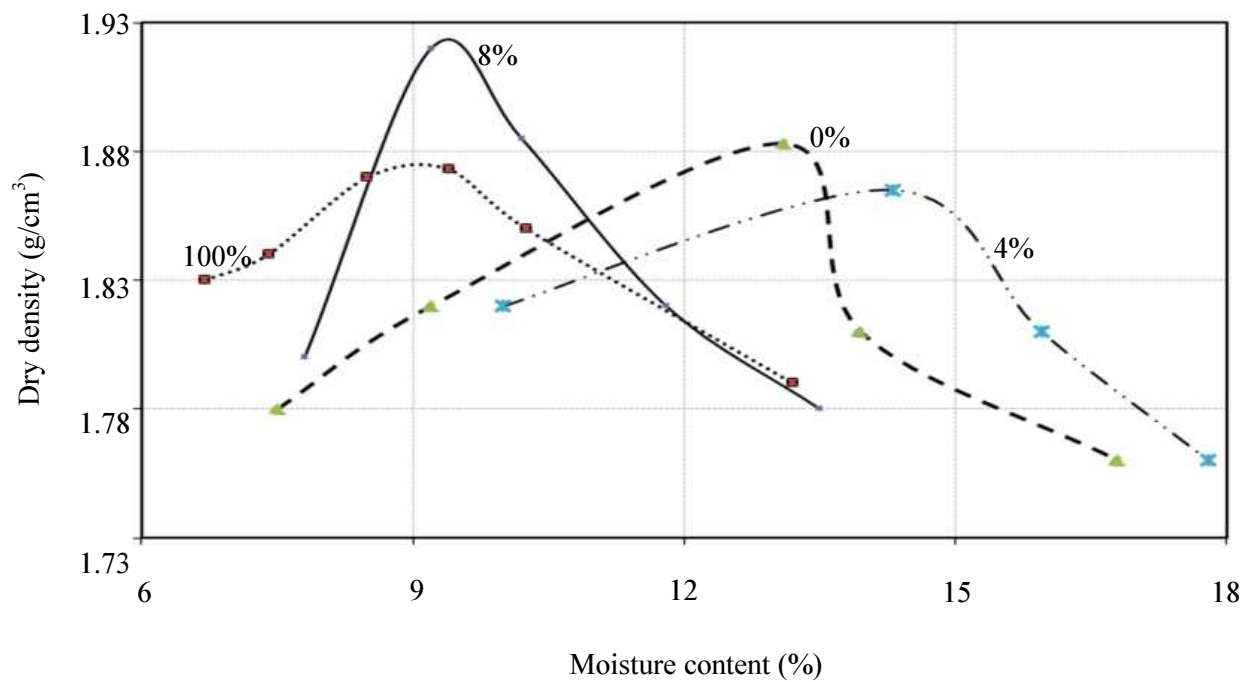

Fig. 2: Moisture content-dry density relation curves 


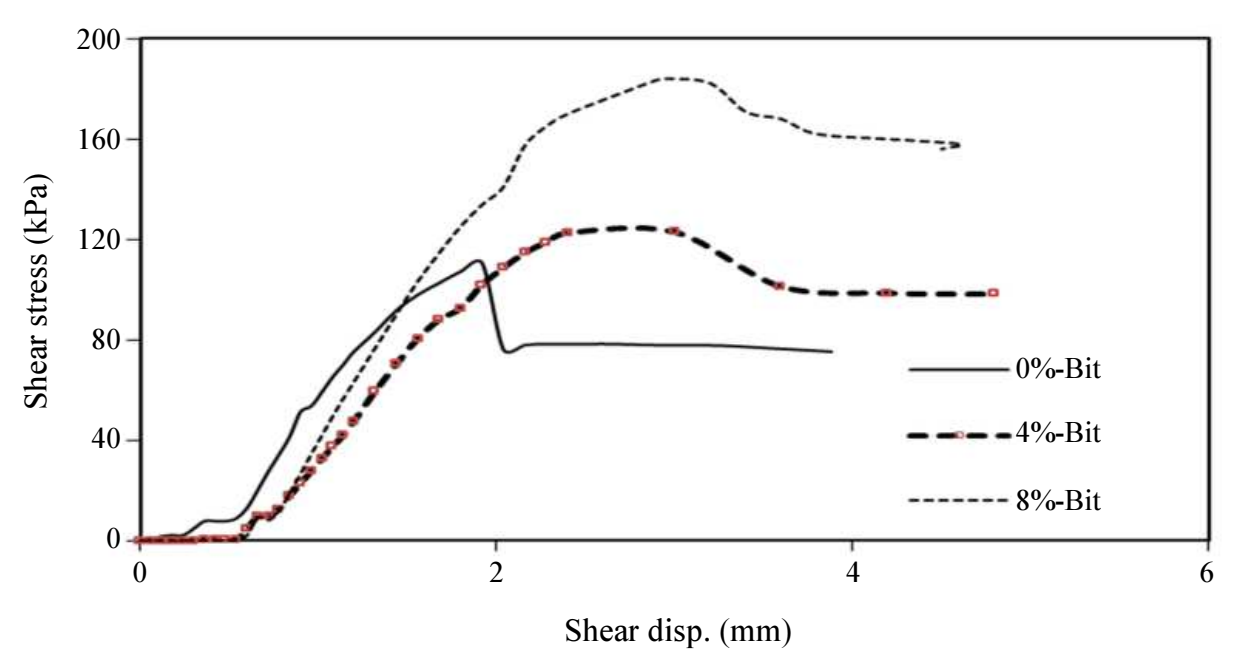

Fig. 3: Shear stress - shear displacement for tested samples at vertical stress $100 \mathrm{kpa}$ in the dry condition

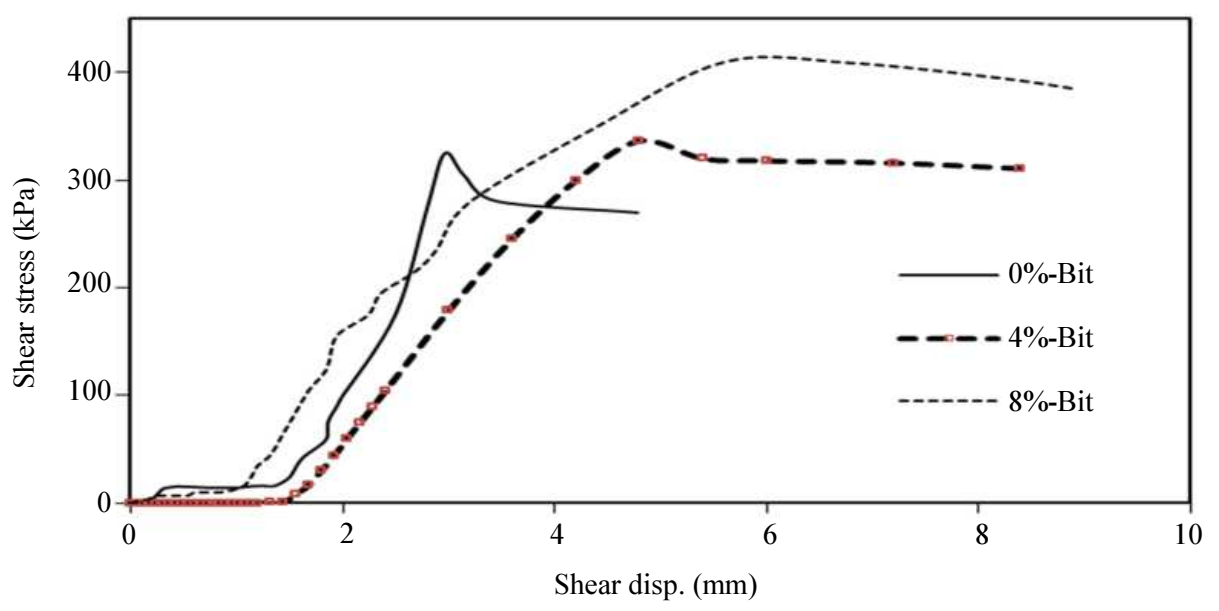

Fig. 4: Shear stress- shear displacement for tested samples at vertical stress $400 \mathrm{kPa}$ in the dry condition

A similar pattern is observed in Fig. 4, which presents the shear stress-displacement for $0 \%, 4 \%$ and $8 \%$ tested samples at a vertical stress of $400 \mathrm{kPa}$. Another interesting aspect of the previous figures is the similarity in the trend for almost every tested soil sample. The figures suggest that shear stress increases with bitumen addition at different vertical stresses.

A closer look at the stress-strain curves for the $0 \%$, $4 \%$ and $8 \%$ mixed sabkha soil samples revealed that bitumen addition increased the displacement required to mobilize the peak shear stresses. For example, as shown in Fig. 3, shear displacement for natural sabkha soil was $1.9 \mathrm{~mm}$, while under the same vertical stresses, shear displacement for the $8 \%$ bitumenmixed sample was $2.88 \mathrm{~mm}$. The ductile failure observed for the bitumen mixed sabkha soil samples can be attributed to the viscous adsorbed layer that surrounds cemented soil particles.

\section{Shear Stress - Horizontal Displacement - Soaked Conditions}

The effect of saturation on the stress-strain relationship for natural sabkha soils for some of the tested soil samples is illustrated in Fig. 5 and 6.

The figures show that shear stresses for the natural sabkha soil samples fell by more than $75 \%$ upon soaking. This high reduction may be linked to salt dissolution, which interfered with the bonding between soil particles.

The effects of bitumen addition on the stress-strain curves for dry and soaked sabkha soil samples at different vertical stresses are shown in Fig. 7, 8 and 9. A comparison of natural and bitumen sabkha soil samples tested under soaked conditions at the same vertical stress is given in Fig. 7. The peak shear stress for $4 \%$ bitumen-mixed sample shown in the figure 
was almost three times greater than the natural sabkha soil sample upon soaking.

The effect of bitumen addition is clearly shown in Fig. 8, where it can be observed clearly that the shear strength of the $4 \%$ bitumen-mixed sabkha soils tested under soaked condition was $14 \%$ lower than the dry sample.
The effect of the amount of bitumen in the bitumen-mixed sabkha soil sample on the soaked condition shear strength value is clearly shown in Fig. 8. The reduction in the peak shear stress for the soil samples tested under soaked conditions fell with an increase in the bitumen content.

Table 3: Indicated to the values of $\left(\varphi_{\mathrm{f}}\right)$ and $(\mathrm{C})$ for natural and bitumen mixed samples under dry and soaked condition

\begin{tabular}{lllr}
\hline Test condition & Bitumen $(\%)$ & Internal angle of & \multicolumn{1}{c}{$\begin{array}{c}\text { Cohesion Intercept } \\
(\mathrm{C})(\mathrm{kPa})\end{array}$} \\
\hline Dry & 0 & friction $\left(\Phi_{\mathrm{f}}\right)($ Degree $)$ & 90.0 \\
& 4 & 25.0 & 75.0 \\
Soaked & 8 & 24.0 & 105.0 \\
& 0 & 27.0 & 10.0 \\
& 4 & 10.0 & 60.0 \\
\hline
\end{tabular}

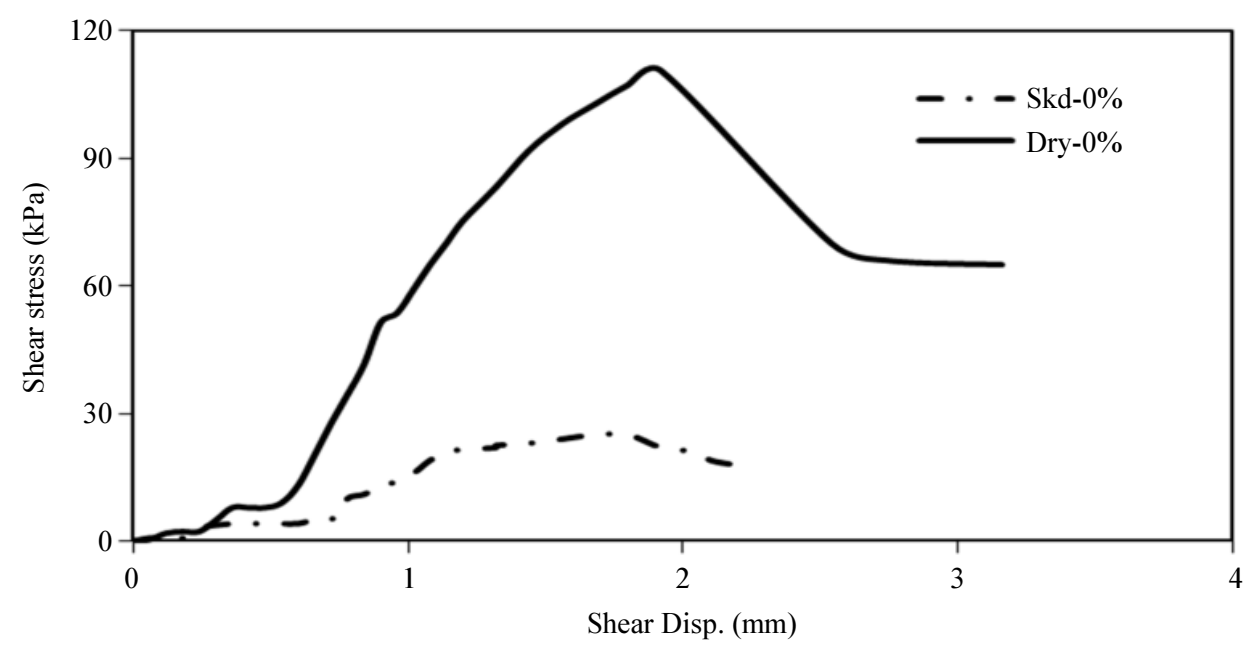

Fig. 5: Shear stress- shear displacement for soaked and dry $0 \%$ bitumen mixed samples at vertical stress $100 \mathrm{kPa}$

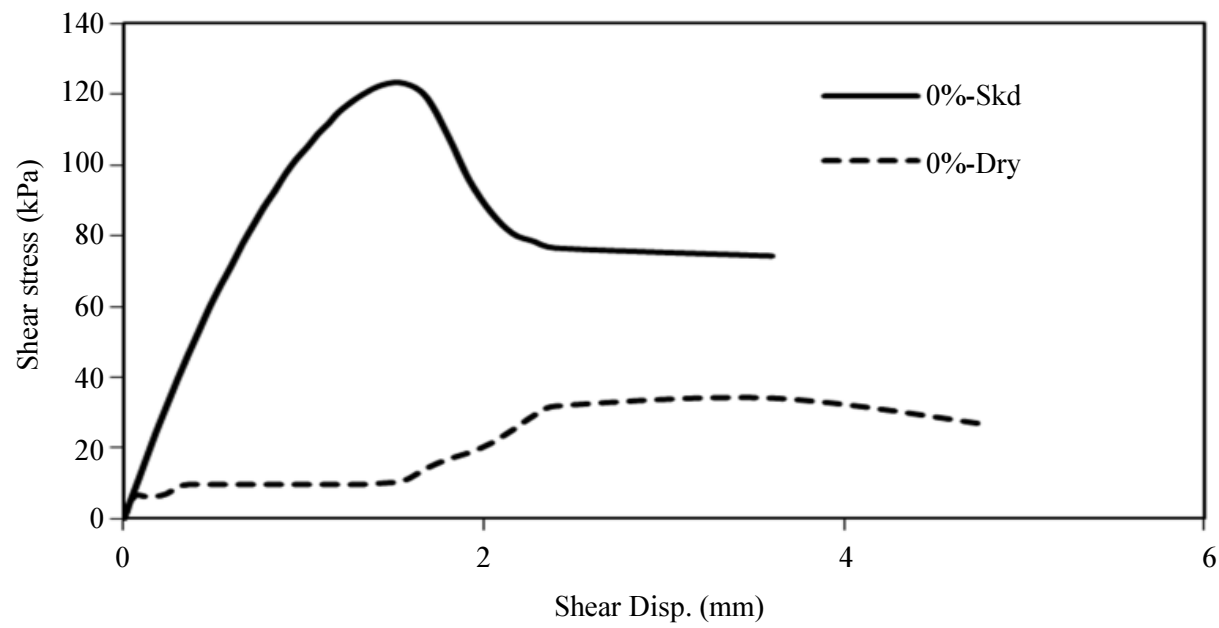

Fig. 6: Shear stress - shear displacement for soaked and dry $0 \%$ bitumen mixed samples at vertical stress $150 \mathrm{kPa}$ 


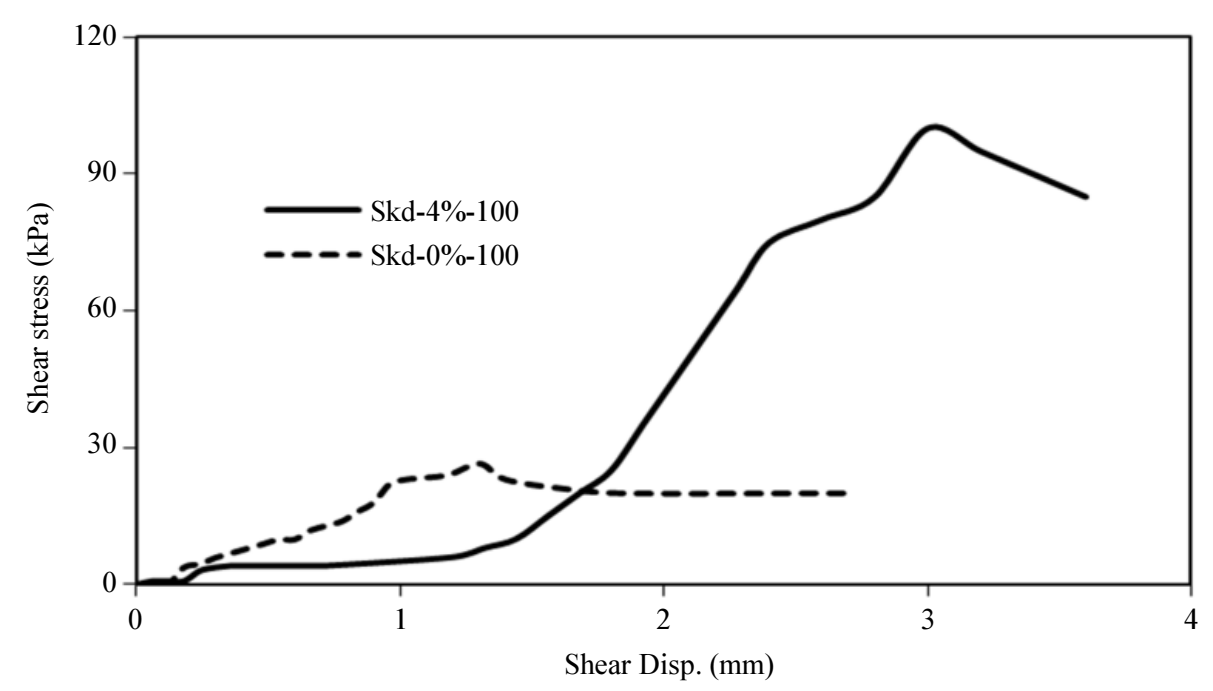

Fig.7: Shear stress - shear displacement for soaked $0 \%$ and $4 \%$ bitumen mixed samples at vertical stress $100 \mathrm{kPa}$

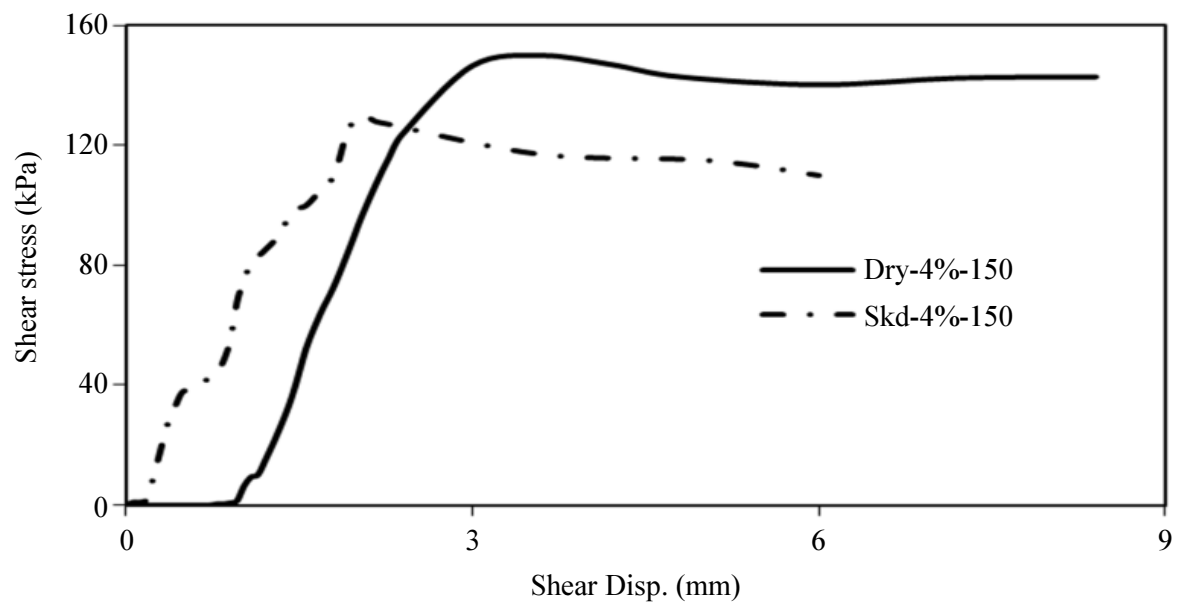

Fig. 8: Shear stress - shear displacement for dry and soaked samples at vertical stress $150 \mathrm{kPa}$

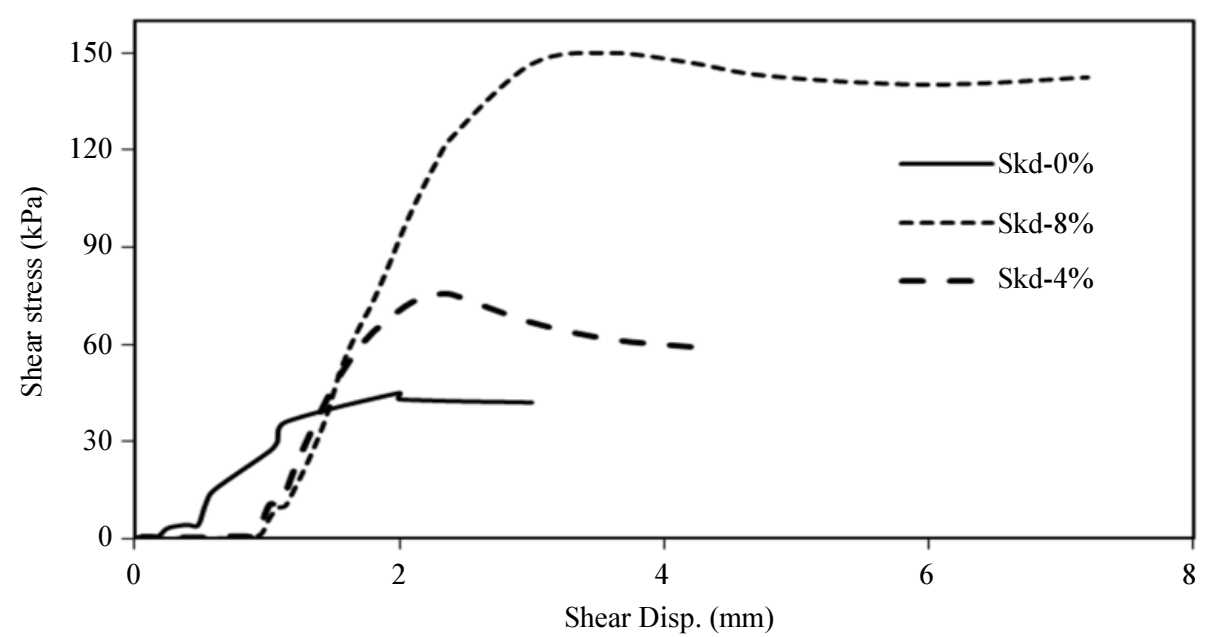

Fig. 9: Shear stress - shear displacement for soaked $0 \%, 4 \%$ and $8 \%$ bitumen mixed samples at vertical stress $150 \mathrm{kPa}$ 


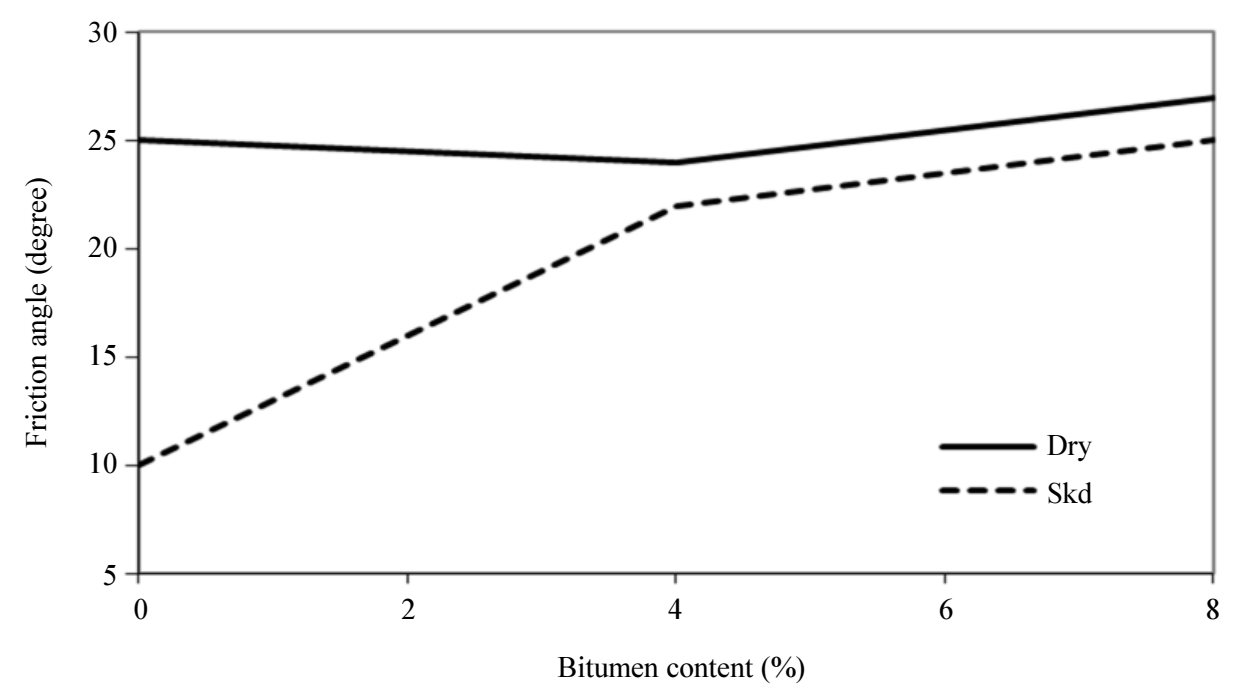

Fig. 10: Variation of ( $\varphi$ f) values with bitumen contents under dry and soaked condition

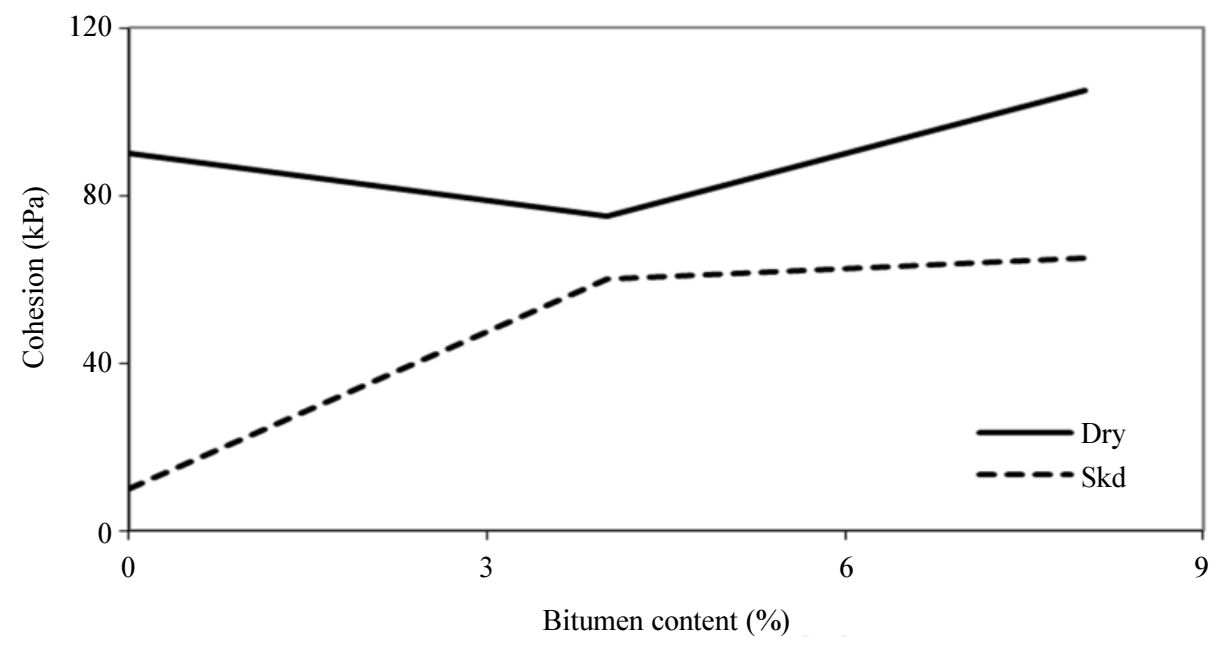

Fig. 11: Variation of (C) values with bitumen contents under dry and soaked condition

\section{Peak Shear Stress/Normal Stress Relationships}

Table 3 summarizes data for the internal angle of friction $(\varphi f)$ and cohesion intercept $(C)$ for the natural and bitumen-mixed soil samples tested under dry and soaked conditions. The results indicate that under dry conditions, $\varphi f$ increased slightly with $8 \%$ bitumen addition. An increase of $17 \%$ in the value of $\mathrm{C}$ was observed at the same bitumen percentage.

The $\varphi f$ and $C$ values for different bitumen conditions are represented graphically in Fig. 10 and 11. As shown in Fig. 10, the soil samples displayed a trend of gentle reduction in the $\varphi f$ value with bitumen addition up to $4 \%$. Beyond $4 \%$, $\varphi$ f increased to a higher value. A similar trend was observed for the $\mathrm{C}$ values with bitumen addition.

Bitumen addition prevented shear strength loss of the sabkha soils upon soaking. The significant reduction in the $\varphi \mathrm{f}$ and $\mathrm{C}$ values for natural soil upon soaking can be attributed to internal fabric attenuations, including the destruction of bonds, weakening of cementation and breakdown of soil packets (Al-Awaji, 2001). This is because salt-cemented soils owe much of their shear strength to their cementation (Al-Sanad, 1986). Similar findings have been reported by Ismael et al. (1986) based on soaked and non-soaked direct shear tests. The experiments were also undertaken on natural sabkha soils and the authors observed a $\varphi f$ reduction of calcareous desert sands due to saturation.

Results for the bitumen-mixed sabkha soil samples suggested that bitumen addition reduced the effect of soaking on the shear stress parameter and shear strength. The results further indicated that shear stress loss in bitumen-mixed soils was lower than that in natural soil. This may be attributable to the 
waterproofing effect of bitumen, which prevents the dissolution of salts and reduction in cementation. In summary, bitumen addition prevented shear strength loss of compacted sabkha soils upon soaking.

\section{Conclusion}

This paper investigated the effects of bitumen addition on the shear strength characteristics of sabkha soil samples under dry and soaked conditions. The study involved physical and chemical soil characterization, modified compaction tests (i.e., mixed with different amounts of bitumen, including $0 \%, 4 \%, 8 \%$ and $10 \%$ ) and direct shear strength tests on $0 \%, 4 \%$ and $8 \%$ bitumen-mixed sabkha soil samples. Based on the results, the following conclusions are drawn from this part of the experimental work:

- The compaction characteristics of the bitumenmixed sabkha soil are modified by a bitumen addition of up to $8 \%$. This percentage is expected to vary between sabkhas and other soils due to chemical differences

- $\quad$ Peak shear stresses slightly increased with bitumen addition at different applied vertical stresses for the sabkha soil samples

- Larger displacements were required to mobilize peak shear stresses for bitumen-mixed sabkha soil samples than natural sabkha soil samples

- Shear strength parameters were affected by bitumen addition: Namely, $\varphi f$ and $C$ values increased at different rates in the bitumen addition range of $8 \%$

- Both natural and bitumen-mixed sabkha soils were affected by soaking. However, the reduction in the peak shear stress value was very low for the bitumen-mixed sabkha samples

- $\quad$ Reduction in the peak shear stress value lessened with bitumen addition

- $\quad$ The adsorbed bitumen layer on the cemented soil lumps acted as a waterproofing agent that reduced salt dissolution and alternatively reduced the effect of soaking on the shear stress parameter

\section{Future Research}

Further investigation should be carried out to examine other geotechnical properties of bitumen-mixed sabkha soil.

\section{Acknowledgment}

The authors are grateful to the Ministry of Electricity field staff (south area), for their valuable help during soil survey and sampling in August 2017.

\section{Funding Information}

The sampling and experimental process were financially supported by the authors.

\section{Author's Contributions}

Fahad Alotaibi: Conducted soil sample collection, experimental setup, sample testing and writing the manuscript.

Humoud Aldaihani: Make samples testing, design the results analysis and writing the manuscript.

\section{Ethics}

This article is original and contains unpublished material. It is confirmed that all authors have read and approved the manuscript and there are no ethical issues involved.

\section{References}

Al-Abdul Wahhab, H.I. and I.M. Asi, 1997. Improvement of marl and dune sand for highway construction in arid areas. Build. Environ., 32: 271-279. DOI: 10.1016/S0360-1323(96)00067-4

Akpokodje, E.G., 1985. The stabilization of some arid zone soils with cements and lime. Quarterly J. Eng. Geol. Hydrogeol., 18:173-180.

DOI: 10.1144/GSL.QJEG.1985.018.02.06

Al-Amoudi, O.S.B. and S.N. Abduljauwad, 1995. Compressibility and collapse characteristics of arid saline sabkha soils. Eng. Geol., 39: 185-202. DOI: 10.1016/0013-7952(95)00016-9

Al-Amoudi, O.S.B., I.M. Asi and Z.R. El-Naggar, 1995. Stabilisation of an arid, saline sabkha soil using additives. Quarterly J. Eng. Geol., 28: 369-379. DOI: 10.1144/GSL.QJEGH.1995.028.P4.06

Al-Amoudi, O.S.B., 2002. Characterisation and chemical stabilisation of Al-Qurayyah sabkha soil. J. Mater. Civil Eng., 14: 478-484.

DOI: 10.1061/(ASCE)0899-1561(2002)14:6(478)

Al-Amoudi, O.S.B., 1994. Chemical stabilisation of sabkha soils at high-moisture contents. Eng. Geol., 36: 279-291. DOI: 10.1016/0013-7952(94)90009-4

Al-Awaji, H.A., 2001. Settlement and bearing capacity of geogrid-reinforced sand over collapsible soil. Geotextiles Geo-Membranes, 19: 75-88.

DOI: 10.1016/S0266-1144(01)00002-4

Aldaihani, H.M.Z., 2017. A geotechnical, geochemical and human health risk assessment of a dry oil lake site in Kuwait. PhD Thesis, University of Portsmouth, United Kingdom, UK.

Al-Otaibi, F.A. and F.M. Wegian, 2012. Investigation the effect of bitumen content on ion dissolution in bitumen mixed sabkha soil. Kuwait J. Sci. Eng., 39: 93-109. 
Al-Otaibi, F.A., F.M. Wegian, A.A. Alnaki, S.K.H. Almutairi and R.M. Singhd, 2012. Effect of bitumen addition on the long-term permeability of sabkha soil. Kuwait J. Sci. Eng., 39: 131-148.

Al-Otaibi, F.A., 2006. An assessment of the possibility of stabilizing sabkha soils using oil lake residuereuse of waste materials. $\mathrm{PhD}$ Thesis, Cardiff University, Wales, UK.

Al-Sanad, H.A., 1986. Characterisation of salt-bearing soils (sabkha) for pavement design purposes in the state of Kuwait. J. Univ. Kuwait-Sci., 13: 29-41.

Al-Shamrani, M.A. and A.W. Dhowian, 1997. Preloading for reduction of compressibility characteristics of sabkha soil profiles. Eng. Geol., 48: 19-41. DOI: 10.1016/S0013-7952(97)81912-6

ASTM D-854, 2014. Standard test methods for specific gravity of soil solids by water pycnometer (Report No. D854-14). ASTM, West Conshohocken, Philadelphia (Pa), USA.

ASTM D-1557, 2012. Standard test methods for laboratory compaction characteristics of soil using modified effort $(56,000 \mathrm{ft}-\mathrm{Ibf} / \mathrm{ft} 3(2,700 \mathrm{KN}-\mathrm{m} / \mathrm{m} 3))$ (Report No. D1556-12e1). ASTM, West Conshohocken, Philadelphia (Pa), USA.

ASTM D-2487, 1999. Annual book of ASTM standards, standard classification of soils for engineering purposes (Unified Soil Classification System) (Report No. D-2487). ASTM, West Conshohocken, Philadelphia $(\mathrm{Pa})$, USA.

ASTM D-422, 1998. Annual book of ASTM standards, standard test method for particle-size analysis of soils. ASTM, West Conshohocken, Philadelphia $(\mathrm{Pa})$, USA.

ASTM D-3080, 1998. Annual book of ASTM standards, standard test method for direct shear test of soils under consolidated drained condition. ASTM, West Conshohocken, Philadelphia (Pa), USA.
ASTM D-4318, 1995. Annual book of ASTM standards, standard test method for liquid limit, plastic limit and plasticity index of soils (Report No. D-4318). ASTM, West Conshohocken, Philadelphia (Pa), USA.

Asi, I.M., 2001. Stabilisation of sabkha soil using foamed asphalt. J. Mater. Civil Eng., 13: 325-325. DOI: 10.1061/(ASCE)0899-1561(2001)13:5(325)

Asi, I.M., H.I. Al-Abdul Wahhab, O.S. Al- Amoudi, M.I. Khan and Z. Siddiqi, 2002. Stabilisation of dune sand using foamed asphalt. Geotech. Test. J., 25: 168-176. DOI: 10.1520/GTJ11360J

Bell, F.G., 1996. Lime stabilization of clay minerals and soils. Eng. Geol., 42: 223-237.

DOI: 10.1016/0013-7952(96)00028-2

DANA, 1994. Soil Stabilization of Pavement. Department of the Army, Report No. TM 5-822-14, Air Force AFJMAN 32-109, The Navy and Air Force, Washington, D.C.

Ingles, O.G. and J.B. Metcalf, 1972. Soil Stabilization: Principles and Practice. 1st Edn.,Butterworths, Sydney, ISBN-10: 0409482153, pp: 374.

Ismael, N.F. and M.A. Mollah, 1998. Leaching effects on properties of cemented sands in Kuwait. J. Geotech. Geoenviron. Eng., 124: 997-1004. DOI: 10.1061/(ASCE)1090-0241(1998)124:10(997)

Ismael, N.F., 1993. Geotechnical characteristics of salt bearing soils in Kuwait.Transport. Res. Record J. Transport. Res. Board, 1406: 68-76.

Ismael, N.F., M.A. Mollah and O. Al-Khaldi, 1986. Geotechnical properties of cemented soils in Kuwait. Austral. Road Res., 16: 94-104.

Ngowi, A.B., 1997. Improving the traditional earth construction: A case study of Botswana. Construct. Build. Mater., 11: 1-7. DOI: 10.1016/S0950-0618(97)00006-8 